\title{
Physiological and Genetic Characterization of a Diazotrophic Pseudomonad
}

\author{
By YIU-K WOK CHAN*, ROGER WHEATCROFT AND \\ ROBERT J. WATSON \\ Chemistry and Biology Research Institute, Research Branch, Agriculture Canada, Ottawa, \\ Ontario, Canada K1A 0C6
}

(Received 27 January 1986; revised 1 April 1986)

\begin{abstract}
A soil isolate, $4 \mathrm{~B}$, which had been previously assigned to the genus Pseudomonas and shown to be capable of reducing $\mathrm{C}_{2} \mathrm{H}_{2}$ with simple phenolic compounds as sole carbon source, was further characterized in comparison with two other diazotrophs which were identified as pseudomonads. The DNA base composition of $4 \mathrm{~B}$ was $60 \cdot 2 \mathrm{~mol} \% \mathrm{G}+\mathrm{C}$. Plasmid DNA was not detected in alkaline SDS lysates of $4 \mathrm{~B}$ by agarose gel electrophoresis. Comparable maximum $\mathrm{C}_{2} \mathrm{H}_{2}$ reduction activities in $4 \mathrm{~B}$ were observed under microaerobic conditions $\left(\mathrm{pO}_{2}\right.$ about $\left.0.003 \mathrm{~atm}\right)$ with either $28 \mathrm{~mm}$-glucose or $5 \mathrm{~mm}$-protocatechuate as carbon source. $\mathrm{N}_{2}$ fixation was confirmed by the cellular incorporation of ${ }^{15} \mathrm{~N}_{2}$ in cultures of $4 \mathrm{~B}$ grown in $\mathrm{N}$-free medium. Extensive biochemical tests, including the carbon utilization pattern, demonstrated that $4 \mathrm{~B}$ was closely related to Pseudomonas delafieldii (ATCC 17505) although the latter did not fix $\mathrm{N}_{2} .4 \mathrm{~B}$ had metabolic patterns different from the two other strains reported to be diazotrophic pseudomonads; all three contained DNA homologous to the nifHDK genes of Klebsiella pneumoniae M5A1.
\end{abstract}

\section{INTRODUCTION}

Diazotrophy is widespread among prokaryotic micro-organisms (for review see Postgate, 1981,1982 ). The diverse habitats of the $\mathrm{N}_{2}$-fixing bacteria include soil, aquatic, plant and animal ecosystems (Knowles, 1977, 1978). In such diverse environments different physiological requirements for optimal $\mathrm{N}_{2}$ fixation, such as adjustment to energy source and oxygen concentration, have been evolved by these bacteria. Yet, all diazotrophs examined to date have been found to possess similar nitrogenase enzyme systems which are encoded by the highly conserved nif genes (Brill, 1980; Elmerich, 1984; Ruvkun \& Ausubel, 1980).

Recently, two diazotrophic bacteria isolated from grass roots have been described (Barraquio et al., 1983; Haahtela et al., 1983). These have been identified as pseudomonads; yet there is no general agreement that the genus Pseudomonas includes diazotrophic species (Balandreau, 1983; Postgate, 1982; Palleroni, 1984). These isolates showed Pseudomonas-like properties upon gel immunodiffusion and in fluorescent antibody and lipopolysaccharide analyses, in addition to their morphological, cultural and biochemical characteristics. One of us (Chan, 1986) has also previously described a diazotrophic bacterium (designated 4B) which was isolated from a forest soil and tentatively identified as a Pseudomonas species. Its nitrogenase $\left(\mathrm{C}_{2} \mathrm{H}_{2}\right.$ reduction) activity was supported by simple phenolic compounds as the sole carbon and energy source. We report here a more detailed physiological and genetic characterization of 4B which justifies its inclusion in the genus Pseudomonas and suggests that it is a new species. Proof of its diazotrophy is presented by ${ }^{15} \mathrm{~N}_{2}$ incorporation as well as DNA homology with the nif structural genes of Klebsiella pneumoniae. A preliminary account of this investigation was presented at the Sixth International Symposium on Nitrogen Fixation, 4-10 August 1985, Corvallis, Oregon, USA. 


\section{METHODS}

Bacterial strains, plasmids and DNA. Strain 4B, which has been tentatively assigned to the genus Pseudomonas, was originally isolated from a forest soil (Chan, 1986) and was recently deposited in the American Type Culture Collection (ATCC 43038). P. delafieldii (ATCC 17505) and P. putida (ATCC 33015) were obtained from the ATCC. Pseudomonas strain H8 (ATCC 35402) was a gift from W. L. Barraquio (Department of Microbiology, Macdonald Campus of McGill University, Canada). Pseudomonas strain DC, originally isolated from the roots of the grass Deschampsia caespitosa (Haahtela et al., 1983), was kindly sent to us by K. Haahtela (University of Helsinki, Finland). Klebsiella pneumoniae M5A1 was obtained from V. N. Iyer, (Carleton University, Ottawa, Canada); Escherichia coli J53 (proA metF $\lambda$ ) carrying plasmid RP4 (Apr $\mathrm{Km}^{\mathrm{r}} \mathrm{Nm}^{\mathrm{r}} \mathrm{Tc}^{\mathrm{r}}$ ) was from the Plasmid ReferenceCenter, Stanford University, USA ; E. coli B was from the Department of Microbiology, University of Manitoba, Canada; and E. coli HB101(pSA30) was from D. R. Helinski, (University of California, USA).

Reference DNAs of Clostridium perfringens, E. coli B and Micrococcus lysodeikticus were purchased from Sigma.

Culture media. The maintenance agar used for the diazotrophic species consisted of $0 \cdot 1 \%(w / v)$ Difco tryptic soy broth solidified with $1.6 \%(\mathrm{w} / \mathrm{v})$ Difco Bacto-agar; $P$. delafieldii was maintained on nutrient agar. Tests for autotrophic growth with $\mathrm{H}_{2}, \mathrm{O}_{2}$ and $\mathrm{CO}_{2}$ were done in the defined medium described by De Bont \& Leijten (1976). The modified Burk's $\mathrm{N}$-free liquid medium (Dalton, 1980) with either $28 \mathrm{mM}$-glucose or 5 mM-protocatechuate as carbon source was used for the cultivation of $\mathrm{N}_{2}$-fixing cells and in assays for their nitrogenase activity. Autoclaving was done at $121^{\circ} \mathrm{C}$ and $103.4 \mathrm{kPa}$ for $20 \mathrm{~min}$. All media were prepared with distilled water.

Biochemical and cultural characterization. The comparative characterization of $4 \mathrm{~B}, P$. delafieldii, $\mathrm{H} 8$ and $\mathrm{DC}$ was done according to Stanier et al. (1966) with the following modifications. Growth temperature studies of 4B were done in duplicate screw-cap tubes containing $5 \mathrm{ml} 0 \cdot 1 \%$ tryptic soy broth (pH 6.8) inoculated with $0 \cdot 1 \mathrm{ml}$ of exponential-phase cells. $\mathrm{OD}_{430}$ was determined after incubation at various temperatures for $7 \mathrm{~d}$. Growth dependence on $\mathrm{pH}$ was similarly investigated but the broth was prepared in phosphate/borate buffer adjusted to various $\mathrm{pH}$ values and $\mathrm{OD}_{430}$ was measured after $24 \mathrm{~h}$ incubation at $30^{\circ} \mathrm{C}$.

Autotrophic growth with $\mathrm{H}_{2}$ was assessed in $100 \mathrm{ml}$ of the medium of De Bont \& Leijten (1976) contained in a $250 \mathrm{ml}$ side-arm flask. An exponential-phase culture $(2 \mathrm{ml})$ was added to the flask which was then closed with a Suba-Seal stopper, evacuated and flushed aseptically three times with Ar. The final gas phase was adjusted with filter-sterile gases $\left(\mathrm{H}_{2}, \mathrm{O}_{2}\right.$ and $\mathrm{CO}_{2}$ respectively at 10,5 and $5 \%$, by vol.) to a total pressure of $101 \cdot 3 \mathrm{kPa}$. The flask was incubated at $28^{\circ} \mathrm{C}$ for $7 \mathrm{~d}$. Growth was verified by an increase in $\mathrm{OD}_{430}$ compared to a control without the addition of $\mathrm{H}_{2}$ and $\mathrm{CO}_{2}$.

Heterotrophic denitrification was assayed in buffered peptone medium with $6 \mathrm{~mm}-\mathrm{NaNO}_{3}$ or $\mathrm{NaNO}_{2}$ in the presence or absence of $10 \%(\mathrm{v} / \mathrm{v}) \mathrm{C}_{2} \mathrm{H}_{2}$ as described by Chan (1985). Growth and nitrous oxide production were used as the criteria for positive denitrification.

Presumptive nitrogenase tests were done using the $\mathrm{C}_{2} \mathrm{H}_{2}$ reduction technique in $18 \times 150 \mathrm{~mm}$ test-tubes containing $10 \mathrm{ml}$ modified Burk's medium with $28 \mathrm{~mm}$-glucose solidified with $0.2 \%$ (w/v) agar (Chan, 1986).

DNA base composition was determined by UV-absorption ratios (Ulitzur, 1972) with DNAs from $C$. perfringens, $E$. coli $\mathrm{B}$ and $M$. lysodeikticus as standards.

The carbon utilization pattern of $4 \mathrm{~B}$ was independently confirmed by the Applied Sciences Department of the ATCC using the methods of Stanier et al. (1966).

DNA hybridization and plasmid techniques. Total DNA was isolated from $5 \mathrm{ml}$ of bacterial culture by the method of Marmur (1961), modified to include a treatment with $0.2 \mathrm{mg}$ proteinase $\mathrm{K}$ (Beckman) $\mathrm{ml}^{-1}$, before the extractions with chloroform/isoamyl alcohol. DNA was treated with EcoRI (Boehringer-Mannheim) and the fragments were separated by electrophoresis in a $1.0 \%$ agarose gel. The DNA fragments were transferred onto nitrocellulose paper (Schleicher and Schuell, BA85) as described by Southern (1975). Nick translation of pSA30 was done as described by Rigby et al. (1977) using deoxycytidine $5^{\prime}-\left[\alpha-{ }^{32} \mathrm{P}\right]$ triphosphate $\left[3000 \mathrm{Ci} \mathrm{mmol}^{-1}\right.$ (111 TBq $\mathrm{mmol}^{-1}$ ), New England Nuclear] and DNA polymerase I (Boehringer-Mannheim). Hybridizations weredone in $50 \%$ formamide at $42{ }^{\circ} \mathrm{C}$ but otherwise were as described by Botchan et al. (1976). After washing, the filters were dried and exposed using Kodak XAR-2 film.

Bacterial matings to transfer plasmid RP4 between J53(RP4) and 4B were done on nitrocellulose filter discs on nutrient agar at $34^{\circ} \mathrm{C}$. Kanamycin resistant transconjugants of $4 \mathrm{~B}$ were selected by streaking the mating mixture after $24 \mathrm{~h}$ growth onto Pseudomonas minimal agar containing $10 \mathrm{mM}$-sodium succinate (Murray et al., 1972) and $20 \mu \mathrm{g}$ kanamycin sulphate $\mathrm{ml}^{-1}$. Plasmid DNA was detected in agarose gels as described by Wheatcroft \& Williams (1981) and Eckhardt (1978); pSA30 DNA was purified in a CsCl-ethidium bromide gradient (Guerry et al., 1973).

Nitrogenase assay. Cultures of $4 \mathrm{~B}$ were grown at $22^{\circ} \mathrm{C}$ in 1 litre Erlenmeyer flasks each containing $750 \mathrm{ml}$ modified Burk's N-free medium with either $28 \mathrm{~mm}$-glucose or $5 \mathrm{~mm}$-protocatechuate as the carbon source. The cultures were continuously stirred and sparged with filter-sterilized $1 \% \mathrm{O}_{2}(\mathrm{v} / \mathrm{v})$ in $\mathrm{N}_{2}$ (Matheson Gas Products, Canada) flowing at $250 \mathrm{ml} \mathrm{min}{ }^{-1}$ until early stationary-phase was reached (about $24 \mathrm{~h}$ ). Samples $(9 \mathrm{ml})$ were dispensed into sterile serum bottles $(60 \mathrm{ml}$ capacity). In order to ensure there was sufficient carbon substrate at the 
beginning of the assay, $1 \mathrm{ml}$ sterile solution containing $0.28 \mathrm{mmol}$ glucose was added to each glucose-grown culture sample while $50 \mu \mathrm{mol}$ protocatechuate in $1 \mathrm{ml}$ sterile solution was added to the protocatechuate-grown culture sample. The bottles were then closed with Suba-Seal stoppers, evacuated and back-filled aseptically four times with $\mathrm{He}$.

To determine the optimum $\mathrm{O}_{2}$ concentration for nitrogenase activity, the initial $\mathrm{pO}_{2}$ in sets of triplicate bottles was adjusted to $0,0.001,0.003,0.005,0.0075$ and 0.01 atm. The assay was started by introducing $5 \mathrm{ml} \mathrm{C}_{2} \mathrm{H}_{2}$ into each bottle. The bottles were incubated in a shaking water bath $\left(28^{\circ} \mathrm{C}, 150\right.$ r.p.m. $)$ and ethylene production was monitored by gas chromatography up to $5 \mathrm{~h}$.

For the ${ }^{15} \mathrm{~N}_{2}$ incorporation experiment, after evacuation and back-flushing with $\mathrm{He}, 10 \mathrm{ml}{ }^{15} \mathrm{~N}_{2}(99$ atom $\%$; Merck Sharp \& Dohme Isotopes, Canada) was introduced into each bottle after the same volume of He was withdrawn from the head space. The $\mathrm{pO}_{2}$ was adjusted to 0.003 and 0.005 atm respectively for the glucose and protocatechuate cultures. Triplicate bottles were similarly set up but with the addition of ${ }^{14} N_{2}$ instead of ${ }^{15} N_{2}$. Parallel $\mathrm{C}_{2} \mathrm{H}_{2}$, reduction assays were also done as described above. Ethylene production was found to be constant without lag up to $5 \cdot 2 \mathrm{~h}$.

Gas chromatography. Nitrous oxide was quantified by electron-capture detection (Chan, 1985). $\mathrm{O}_{2}$ and ethylene were measured by thermal conductivity and flame-ionization detectors, respectively (Chan, 1986). All gas analyses were done on $0.1 \mathrm{ml}$ samples.

${ }^{15} \mathrm{~N}$ analysis. The total $\mathrm{N}$ of cells and spent culture medium was determined as $\mathrm{NH}_{4}^{+}$after $\mathrm{Kjeldahl}$ digestion by steam distillation and colour development with Nessler reagent (Keeney \& Nelson, 1982). Undigested samples were converted to $\mathrm{N}_{2}$ by a modified Dumas method and the ${ }^{15} \mathrm{~N}$ content was analysed using an optical emission spectrometer as described by Preston et al. (1981).

Protein determination. Washed cells were assayed for protein, after hydrolysis in $1 \%(\mathrm{w} / \mathrm{v}) \mathrm{Na}_{2} \mathrm{CO}_{3}$ and $0.5 \%$ (w/v) $\mathrm{NaOH}$ by the Lowry method using bovine serum albumin (Sigma) as standard.

Chemicals. All chemicals used were of analytical grade. When in acid form they were neutralized with $\mathrm{NaOH}$ before use. Heat-labile compounds were filter-sterilized before adding to the culture medium.

\section{RESULTS \\ Comparative characterization}

4B has been tentatively identified as a Pseudomonas species based upon morphological and biochemical criteria (Chan, 1986); further biochemical characterization showed that this strain is closely related to $P$. delafieldii. Table 1 summarizes the features of $4 \mathrm{~B}$ pertinent to its classification in comparison with $P$. delafieldii and two Pseudomonas strains, H8 and DC, which have been reported to be diazotrophs (Barraquio et al., 1983; Haahtela et al., 1983).

The DNA G $+\mathrm{C}$ content of $4 \mathrm{~B}(60.2 \mathrm{~mol} \%)$ and the reference pseudomonads were within the range $58-70 \mathrm{~mol} \%$ characteristic for the genus Pseudomonas (Palleroni, 1984). The base compositions of DNA extracted from $\mathrm{H} 8$ and $E$. coli $\mathrm{B}$ were found to be within $4 \%$ of the reported values of 63.8 and $51.3 \mathrm{~mol} \% \mathrm{G}+\mathrm{C}$, respectively (Barraquio et al., 1983; Marmur \& Doty, 1962).

Table 1. Characteristics differentiating Pseudomonas strains 4B, H8, DC and P. delafieldii*

\begin{tabular}{|c|c|c|c|}
\hline Key character & 4B & P. delafieldii & H8 \\
\hline $\mathrm{Mol} \% \mathrm{G}+\mathrm{C}$ of DNA & $60 \cdot 2 \pm 1 \cdot 2$ & $65-66 \dagger$ & $62 \cdot 0$ \\
\hline Fluorescent pigment & $=$ & - & - \\
\hline Arginine dihydrolase & - & - & + \\
\hline Denitrification & - & + & + \\
\hline Autotrophic growth & & & \\
\hline with $\mathrm{H}_{2} / \mathrm{O}_{2} / \mathrm{CO}_{2}$ & - & - & + \\
\hline $\begin{array}{l}\mathrm{C}_{2} \mathrm{H}_{2} \text { reduction } \\
\text { Utilization of : }\end{array}$ & + & - & + \\
\hline Citrate & + & - & - \\
\hline Poly- $\beta$-hydroxybutyrate & + & + & - \\
\hline$p$-Hydroxybenzoate & + & - & - \\
\hline
\end{tabular}

ND, Not determined.

* Refer to Barraquio et al. (1983) and Haahtela et al. (1983) for the respective sources of strains H8 and DC.

† Unconfirmed results from literature (Palleroni, 1984). 


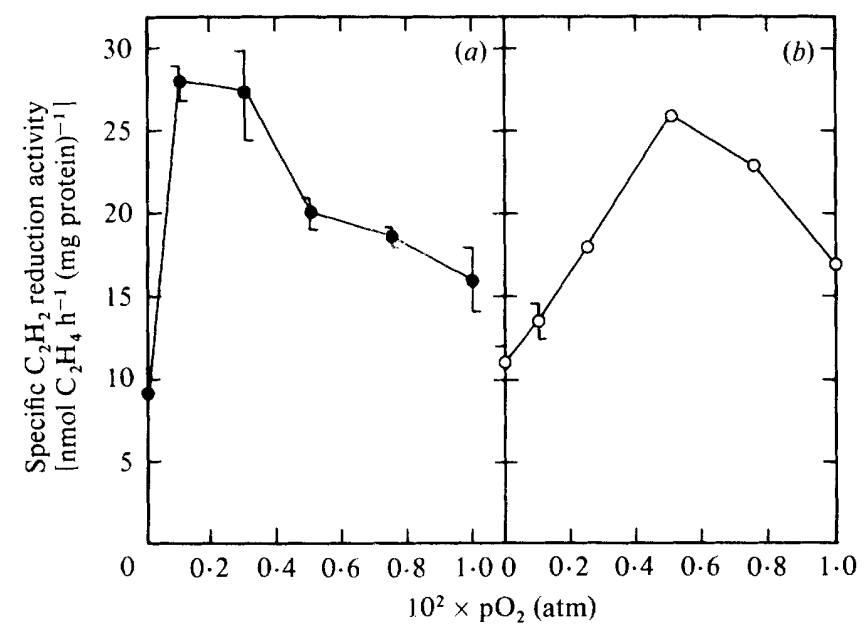

Fig. 1. Effect of initial $\mathrm{pO}_{2}$ on the $\mathrm{C}_{2} \mathrm{H}_{2}$ reduction activity of cultures of Pseudomonas 4B (about $2 \mu \mathrm{g}$ cell protein $\mathrm{ml}^{-1}$ ) provided with $(a) 28 \mathrm{~mm}$-glucose or $(b) 5 \mathrm{~mm}$-protocatechuate as the sole carbon source in $\mathrm{N}$-free medium. Data points and vertical bars represent means of triplicate cultures and SD values, respectively, determined in time-course experiments for up to $5 \mathrm{~h}$ incubation. Where not shown, bars are encompassed by symbols.

Pseudomonas 4B shared several metabolic properties with $P$. delafieldii (Table 1). Neither had arginine dihydrolase activity nor was able to grow autotrophically with exogenous $\mathrm{H}_{2}$, although $P$. delafieldii is phenotypically very similar to the autotrophic $\mathrm{H}_{2}$-utilizing pseudomonads (Davis et al., 1970; Palleroni, 1984). Denitrification, a character which is considered useful for differentiating the $\mathrm{H}_{2}$-utilizing pseudomonads (Davis et al., 1970), was not detected in 4B but, contrary to a previous report (Davis et al., 1970), $P$. delafieldii was found to denitrify. Both $\mathrm{H} 8$ and DC utilized $\mathrm{H}_{2}$, and $\mathrm{H} 8$ was also capable of denitrification (Table 1; Chan, 1985).

Strain $4 \mathrm{~B}$ had a more extensive carbon utilization profile than $P$. delafieldii when 52 organic compounds were individually tested as the sole carbon source for growth. The additional carbon compounds utilized were citrate, $p$-hydroxybenzoate, maltose, rhamnose, L-tryptophan and valerate. Tween 20 and 80 were hydrolysed by 4B but not by $P$. delafieldii. 4B also produced acid from the following carbohydrates in an O-F base (Hugh \& Leifson, 1953): L-arabinose, Dfructose, D-glucose, glycerol, inositol, D-mannose, L-rhamnose, D-ribose and D-xylose. Thus strains 4B, H8 and DC have different metabolic patterns despite their common diazotrophic property.

\section{Physiological characterization of $4 B$}

The maximum growth rate of $4 \mathrm{~B}$ in $0.1 \%$ tryptic soy broth (pH 6.8) was at $34{ }^{\circ} \mathrm{C}$; however, the rate did not vary greatly over the temperature range $25-44{ }^{\circ} \mathrm{C}$. At $30^{\circ} \mathrm{C}$ optimum growth took place over a narrow $\mathrm{pH}$ range with a maximum at $\mathrm{pH} 6 \cdot 2$.

$4 \mathrm{~B}$ was previously shown to reduce $\mathrm{C}_{2} \mathrm{H}_{2}$ using either a carbohydrate (glucose) or a phenolic compound ( $p$-hydroxybenzoate or protocatechuate) as the sole carbon and energy source (Chan, 1986). Fig. 1 shows that maximum $\mathrm{C}_{2} \mathrm{H}_{2}$ reduction, whilst being comparable in rate, occurred at a higher initial $\mathrm{pO}_{2}$ when protocatechuate was used as the substrate $(0.005 \mathrm{~atm})$ rather than glucose $(0.001-0.003 \mathrm{~atm})$. This indicates a different tolerance or requirement for $\mathrm{O}_{2}$ by $4 \mathrm{~B}$ growing with the different carbon sources under $\mathrm{N}_{2}$-fixing conditions.

$\mathrm{N}_{2}$ fixation was confirmed by cellular incorporation of ${ }^{15} \mathrm{~N}_{2}$ in cultures of $4 \mathrm{~B}$ provided with their optimal initial $\mathrm{pO}_{2}$ for $\mathrm{C}_{2} \mathrm{H}_{2}$ reduction determined above (Table 2). Diazotrophic activities were high in both protocatechuate- and glucose-supported cultures. Fixed $\mathbf{N}$ in the spent medium due to excretion and cytolysis was estimated to be $16-18 \%$ of the total ${ }^{15} \mathrm{~N}_{2}$ fixed. 
Table 2. Nitrogenase activity of Pseudomonas 48 supported by 5 mм-protocatechuate or $28 \mathrm{~mm}$ glucose as carbon source

Triplicate cultures each containing about $20 \mu \mathrm{g}$ protein in $10 \mathrm{ml}$ Burk's $\mathrm{N}$-free medium were incubated for $24 \mathrm{~h}$ at $28^{\circ} \mathrm{C}$ with $0.2 \mathrm{~atm}{ }^{15} \mathrm{~N}_{2}\left(98.63\right.$ atom\% excess). The initial $\mathrm{pO}_{2}$ was 0.005 atm (for protocatechuate) or $0.003 \mathrm{~atm}$ (for glucose) with $\mathrm{He}$ as the balancing gas. Controls were similarly set up but with ${ }^{14} \mathrm{~N}_{2}$ instead of ${ }^{15} \mathrm{~N}_{2} . \mathrm{C}_{2} \mathrm{H}_{2}$ reduction was assayed in parallel experiments $\left(10 \%, v / v, \mathrm{C}_{2} \mathrm{H}_{2}\right.$; see Methods for details).

Determination

Cellular ${ }^{15} \mathrm{~N}$ (atom $\% \pm \mathrm{SD}$ )

Excess ${ }^{15} \mathrm{~N}$ (atom \%)

Total cell $\mathrm{N}(\mu \mathrm{mol} \pm \mathrm{SD})$

${ }^{15} \mathrm{~N}_{2}$ incorporated in

$24 \mathrm{~h}$ (nmol)

Specific ${ }^{15} \mathrm{~N}_{2}$ fixation activity

[nmol $\mathrm{N}_{2}$ fixed $\mathrm{h}^{-1}$ (mg protein) $\left.{ }^{-1}\right]$

$\mathrm{C}_{2} \mathrm{H}_{4}$ produced in $5.2 \mathrm{~h}$

$(\mathrm{nmol} \pm \mathrm{SD})$

Specific $\bar{C}_{2} \mathrm{H}_{2}$ reduction

activity [nmol $\mathrm{C}_{2} \mathrm{H}_{4} \mathrm{~h}^{-1}$ $\left.(\mathrm{mg} \text { protein })^{-1}\right]$

\begin{tabular}{|c|c|}
\hline \multicolumn{2}{|c|}{ Experiment } \\
\hline Protocatechuate & Glucose \\
\hline $29.85 \pm 3 \cdot 16$ & $18.31 \pm 2.75$ \\
\hline $29 \cdot 31$ & $17 \cdot 75$ \\
\hline $1.32 \pm 0.15$ & $1.74 \pm 0.15$ \\
\hline $196 \cdot 3$ & 156.8 \\
\hline $231 \cdot 7^{*}$ & $181.9 *$ \\
\hline $442 \cdot 1$ & 267.8 \\
\hline $521 \cdot 8^{*}$ & $310 \cdot 6^{*}$ \\
\hline $142 \cdot 7 \pm 3 \cdot 3$ & $202 \cdot 3 \pm 7 \cdot 4$ \\
\hline 1483.4 & $1594 \cdot 4$ \\
\hline
\end{tabular}

* Values corrected for $\mathrm{N}$ lost to the medium.

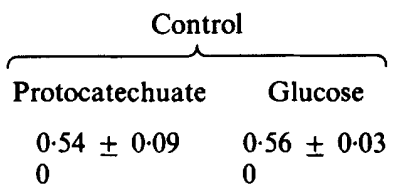

Increase in cellular ${ }^{15} \mathrm{~N}$ enrichment was also observed in cultures incubated up to $72 \mathrm{~h}$ with a high initial $\mathrm{pO}_{2}$ of $0.05 \mathrm{~atm}$. However, these diazotrophic activities were two orders of magnitude lower than those attained with the optimal initial $\mathrm{pO}_{2}$ (data not shown) which further demonstrated that microaerobic conditions were required for optimal $\mathrm{N}_{2}$ fixation by $4 \mathrm{~B}$.

To determine the relationship between $\mathrm{C}_{2} \mathrm{H}_{2}$ reduction and $\mathrm{N}_{2}$ fixation, parallel experiments were set up for the $\mathrm{C}_{2} \mathrm{H}_{2}$ reduction assay (Table 2). Ethylene was produced without any lag at a constant rate up to $5.2 \mathrm{~h}$ when protocatechuate or glucose was present. The molar ratio of ethylene formed to $\mathrm{N}_{2}$ fixed (corrected for $\mathrm{N}$ lost to the medium) ranged from $2 \cdot 8$ to $5 \cdot 1$ for the respective carbon substrates, assuming that the rate of ${ }^{15} \mathrm{~N}_{2}$ fixation was constant during the $24 \mathrm{~h}$ incubation period. The apparent discrepancy in the relative protocatechuate- and glucose-supported nitrogenase activities between ${ }^{15} \mathrm{~N}_{2}$ fixation and $\mathrm{C}_{2} \mathrm{H}_{2}$ reduction is not clearly understood (see Discussion).

\section{Genetic characterization of $4 B$}

The structural genes for nitrogenase are highly conserved among $\mathrm{N}_{2}$-fixing organisms (Ruvkun \& Ausubel, 1980). To determine whether the genomes of $4 \mathrm{~B}, \mathrm{H} 8$ and DC contained DNA sequences homologous to the known structural genes of Klebsiella pneumoniae, the plasmid pSA30 containing the nif HDK genes of $K$. pneumoniae M5Al cloned in pACYC184 was used as a hybridization probe (Cannon et al., 1979). An autoradiogram of EcoRI digests of total DNA from $K$. pneumoniae hybridized with the probe showed a $6.9 \mathrm{~kb}$ band (Fig. 2). No bands were visible in the digested DNA of $P$. putida (ATCC 33015), a control organism which does not reduce $\mathrm{C}_{2} \mathrm{H}_{2}$. However, DNA from $4 \mathrm{~B}, \mathrm{H} 8$ and $\mathrm{DC}$ all showed hybridization bands with pSA30 (Fig. 2). When pACYC184 was used as a probe no homology was observed, demonstrating that the hybridization was attributable to the $K$. pneumoniae DNA of the probe. Hence $4 \mathrm{~B}, \mathrm{H} 8$ and DC all contain DNA homologous to the nif $H D K$ structural genes of $K$. pneumoniae nitrogenase.

No plasmid DNA was detected in strain 4B either by the gentle lysis technique of Eckhardt (1978) or by the alkaline-SDS lysis technique devised for the visualization of Pseudomonas plasmids (Wheatcroft \& Williams, 1981). As it proved possible to detect plasmid RP4 in a transconjugant of $4 \mathrm{~B}$, which was still capable of $\mathrm{C}_{2} \mathrm{H}_{2}$ reduction, it is likely that the nitrogenase genes of $4 B$ are not carried on a plasmid. 


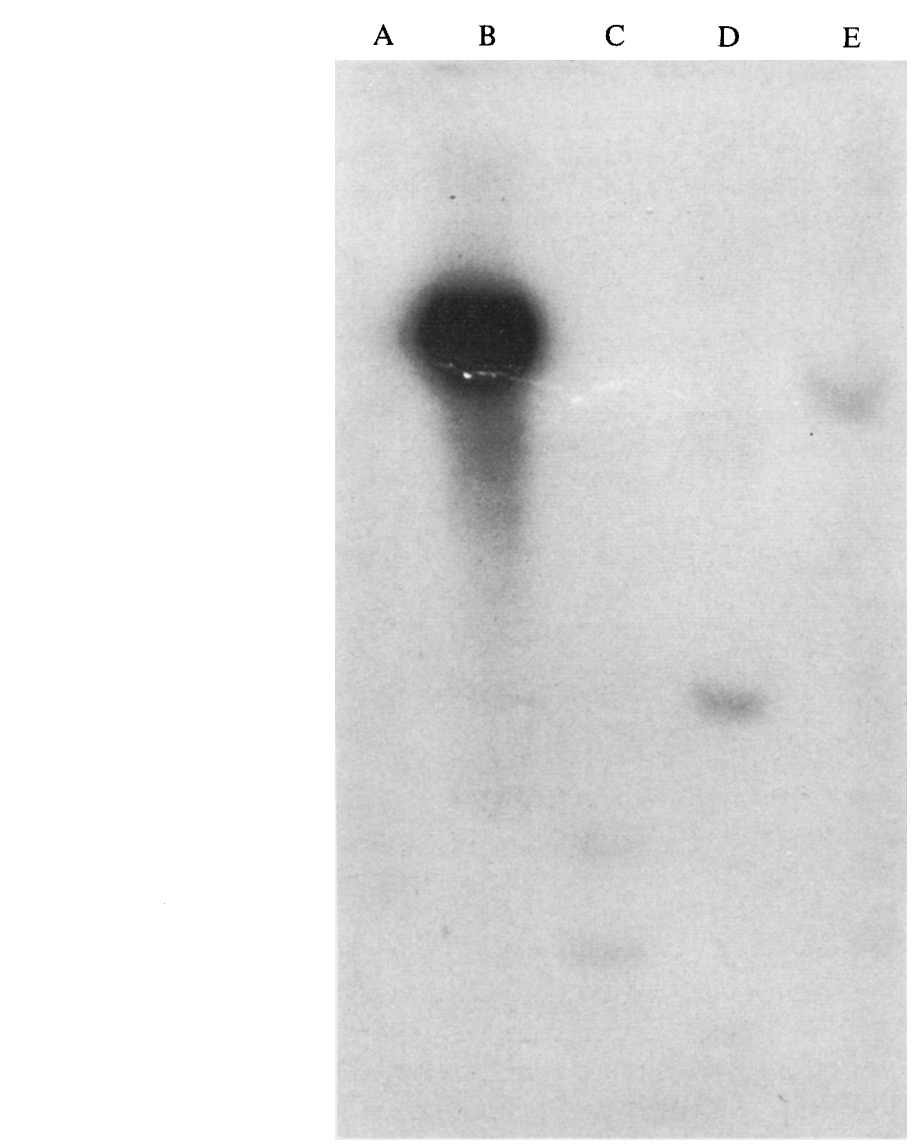

Fig. 2. Autoradiogram showing hybridization of pSA30 to EcoRI digests of total DNA of the following strains (the sizes of the hybridization bands are shown in parentheses): A, P. putida; B, K. pneumoniae M5Al (6.9 kb); C, Pseudomonas 4B (2.0, 1.7 kb); D, Pseudomonas DC (2.7, $1.5 \mathrm{~kb})$; E, Pseudomonas H8 $(5 \cdot 4 \mathrm{~kb})$.

\section{DISCUSSION}

The biochemical and physiological characterization of 4B presented above confirms its initial phenotypic assignment to the genus Pseudomonas (Chan, 1986). It could also be designated as a new diazotrophic species since it differs metabolically from the other two diazotrophic Pseudomonas species H8 and DC (Table 1), reported previously (Barraquio et al., 1983; Haahtela et al., 1983). Although $P$. delafieldii showed a similar, but more restricted, carbon utilization pattern than that of $4 \mathrm{~B}$, it was shown not to reduce $\mathrm{C}_{2} \mathrm{H}_{2}$ (Table 1). Recently, $P$. saccharophila Doudoroff (ATCC 15946) was reported to be the first authenticated Pseudomonas species capable of $\mathrm{N}_{2}$ fixation (Barraquio et al., 1986). It is also known to be able to grow chemolithotrophically with $\mathrm{H}_{2}$. Thus, it is similar to H8 and DC (but different from 4B and $P$. delafieldii) in possessing both $\mathrm{H}_{2}$-utilizing and $\mathrm{N}_{2}$-fixing abilities. However, both $P$. delafieldii and $P$. saccharophila are presently classified in rRNA group III of the genus Pseudomonas and each respectively belongs to the non- $\mathrm{H}_{2}$-utilizing and $\mathrm{H}_{2}$-utilizing subgroups (Palleroni, 1984). Since most $\mathrm{N}_{2}$-fixing bacteria may possess hydrogenase (Robson \& Postgate, 1980), a conventional reversible hydrogenase may be present in 4B. However, nucleic acid hybridization experiments are required to determine the relationship of $4 \mathrm{~B}$ with these pseudomonads.

The genus Pseudomonas has not generally been considered to contain natural diazotrophic species (Palleroni, 1984). This is probably due to a threefold problem in recognizing 
diazotrophic pseudomonads: (i) mistaken or uncertain identification of the diazotroph (De Ley \& Park, 1966; De Smedt et al., 1980); (ii) the lack of rigorous tests for diazotrophy in pseudomonads (Hill \& Postgate, 1969); and (iii) the accepted multigeneric nature of the genus Pseudomonas (De I.ey \& De Vos, 1984; De Vos \& De Ley, 1983). Nevertheless, there is no known reason why diazotrophy should not exist in the genus Pseudomonas (Postgate, 1982). In the case of $4 \mathrm{~B}$, the first two problems have been adequately dealt with by our extensive physiological and genetic characterization. The third problem is, however, inherent in the current taxonomy of the pseudomonads whose phylogeny may have to be more precisely defined (De Vos \& De Ley, 1983). Hence, by the present definition of Pseudomonas, 4B should be recognized as a genuine diazotrophic Pseudomonas species.

The nitrogenase activity (assayed by $\mathrm{C}_{2} \mathrm{H}_{2}$ reduction) of Pseudomonas 4B with protocatechuate as the sole carbon source was previously shown to be highest among the other monomeric phenols, and was about $50 \%$ of that supported by glucose (Chan, 1986). In the present study, where 4B was found to be a microaerophilic diazotroph (Fig. 1), this activity was similar with either carbon substrate when the optimal initial $\mathrm{pO}_{2}$ was used (Table 2). However, the ${ }^{15} \mathrm{~N}_{2}$ fixation activity assayed in parallel showed that the protocatechuate-supported activity was $68 \%$ higher than the glucose-supported activity. This apparent difference may have resulted from lags in ${ }^{15} \mathrm{~N}_{2}$ reduction or unknown factors differentially affecting $\mathrm{N}_{2}$ and $\mathrm{C}_{2} \mathrm{H}_{2}$ reduction. Nevertheless, $\mathrm{N}_{2}$ fixation was proven to have occurred in cultures of $4 \mathrm{~B}$ provided with an aromatic compound (protocatechuate) as the sole carbon and energy source. This supports the suggestion that simple aromatic substrates can serve as important energy sources for significant $\mathrm{N}_{2}$ fixation in plant and soil environments devoid of sugars and organic acids (Chan, 1986).

Pseudomonas species 4B, H8 and DC were all found to contain DNA homologous to the nif $H D K$ genes of $K$. pneumoniae, as determined by probing with plasmid pSA30. No plasmids were detected in $4 \mathrm{~B}$ by using either of the two techniques known to be capable of detecting large plasmids in Pseudomonas and other bacteria. We infer that the nitrogenase structural genes of this strain are located on the chromosome. This has generally been found to be the case amongst free-living diazotrophic bacteria (Robson et al., 1983), though exceptions are known (Derylo et al., 1981; Singh et al., 1983).

In conclusion, a description of Pseudomonas species strain 4B is summarized as follows.

The organism is Gram-negative, non-pigmented, nonspore-forming, rod-shaped (about $0.4 \times$ $1.5 \mu \mathrm{m})$ and motile with polar flagellation. Cells are frequently present in pairs. The optimum growth temperature and $\mathrm{pH}$ are $34^{\circ} \mathrm{C}$ and 6.2 , respectively. Exopolysaccharide is produced in glucose medium. Cells accumulate poly- $\beta$-hydroxybutyrate.

Metabolism is oxidative. Oxidase and catalase are produced. Many organic compounds are utilized for growth. Gelatinase and arginine dihydrolase activities are absent. $\mathbf{N}_{2}$ is fixed without supplements under microaerobic conditions and fixation can be supported by certain aromatic compounds. The organism does not grow autotrophically with $\mathrm{H}_{2}$. Denitrification does not occur but nitrate is reduced to nitrite. The DNA mol $\% \mathrm{G}+\mathrm{C}$ is $60.2 \pm 1 \cdot 2 \mathrm{SD}(n=4$; UV absorption ratio).

The bacterium was isolated from the litter layer of a forest soil (Chan, 1986) and has been deposited with the American Type Culture Collection as ATCC 43038.

We thank Peter Marshall for technical assistance and Karen Burns and Chantal Lafrenière for typing the manuscript. The assistance and advice of Dr C. Preston in the ${ }^{15} \mathrm{~N}$ analysis is appreciated. This paper is Chemistry and Biology Research Institute Contribution No. 1601.

\section{REFERENCES}

Balandreau, J. (1983). Microbiology of the association. Canadian Journal of Microbiology 29, 851859.

Barraquio, W. L., Ladha, J. K. \& Watanabe, I. (1983). Isolation and identification of $\mathrm{N}_{2}$-fixing Pseudomonas associated with wetland rice. Canadian Journal of Microbiology 29, 867-873.

Barraquio, W. L., Padre, B. C., JR, Watanabe, I. \& KNOWLES, R. (1986). Nitrogen fixation by Pseudomonas saccharophila Doudoroff ATCC 15946. Journal of General Microbiology 132, 237-241.

Botchan, M., TopP, W. \& SAMbroOK, J. (1976). The arrangement of Simian virus 40 sequences in the DNA of transformed cells. Cell 9, 269-287. 
BRILL, W. J. (1980). Biochemical genetics of nitrogen fixation. Microbiological Reviews 44, 449-467.

Cannon, F. C., Riedel, G. E. \& Ausubel, F. M. (1979). Overlapping sequences of Klebsiella pneumoniae nif DNA cloned and characterized. Molecular and General Genetics 174, 59-66.

ChaN, Y.-K. (1985). Denitrification by a diazotrophic Pseudomonas species. Canadian Journal of Microbiology 31, 1136-1141.

ChaN, Y.-K. (1986). Utilization of simple phenolics for dinitrogen fixation by soil diazotrophic bacteria. Plant and Soil 90, 141-150.

Dalton, H. (1980). The cultivation of diazotrophic microorganisms. In Methods of Evaluating Biological Nitrogen Fixation, pp. 13-62. Edited by F. J. Bergersen. New York: John Wiley.

Davis, D. H., Stanier, R. Y. \& DoudorofF, M. (1970). Taxonomic studies on some Gram negative polarly flagellated "hydrogen bacteria" and related species. Archives of Microbiology 70, 1-13.

De Bont, J. A. M. \& LeiJten, M. W. M. (1976). Nitrogen fixation by hydrogen-utilizing bacteria. Archives of Microbiology 107, 235-240.

DE LEY, J. \& DE Vos, P. (1984). The genus Pseudomonas. Antonie van Leeuwenhoek 50, 281-283.

De LeY, J. \& PARK, I. W. (1966). Molecular biological taxonomy of some free-living nitrogen-fixing bacteria. Antonie van.Leeuwenhoek 32, 6-16.

Derylo, M., GlowaCKa, M., SKoRUPSKa, A. \& LORKIEWICZ, Z. (1981). Nif plasmid from Lignobacter. Archives of Microbiology 130, 322-324.

De Smedt, J., Bauwens, M., Tytgat, R. \& De Ley, J. (1980). Intra- and intergeneric similarities of ribosomal ribonucleic acid cistrons of free-living, nitrogenfixing bacteria. International Journal of Systematic Bacteriology 30, 106-122.

DE VoS, P. \& DE LeY, J. (1983). Intra- and intergeneric similarities of Pseudomonas and Xanthomonas ribosomal ribonucleic acid cistrons. International Journal of Systematic Bacteriology 33, 487-509.

ECKHARDT, T. (1978). A rapid method for the identification of plasmid deoxyribonucleic acid in bacteria. Plasmid 1, 584-588.

ELMERICH, C. (1984). Molecular biology and ecology of diazotrophs associated with non-leguminous plants. Biotechnology 2, 967-978.

Guerry, P., LeblanC, D. J. \& Falkow, S. (1973). General method for the isolation of plasmid deoxyribonucleic acid. Journal of Bacteriology 116, 10641066.

haAhtela, K., Helander, I., Nurmiaho-Lassila, E.-L. \& Sundman, V. (1983). Morphological and physiological characteristics and lipopolysaccharide composition of $\mathrm{N}_{2}$-fixing $\left(\mathrm{C}_{2} \mathrm{H}_{2}\right.$-reducing) rootassociated Pseudomonas sp. Canadian Journal of Microbiology 29, 874-880.

Hill, S. \& Postgate, J. R. (1969). Failure of putative nitrogen-fixing bacteria to fix nitrogen. Journal of General Microbiology 58, 277-285.

HuGH, R. \& LeIFSON, E. (1953). The taxonomic significance of fermentative versus oxidative metabolism of carbohydrates by various Gram-negative bacteria. Journal of Bacteriology 66, 24-26.

KeENEY, D. R. \& NeLsoN, D. W. (1982). Nitrogeninorganic forms. In Methods of Soil Analysis, part 2, pp. 643-698. Edited by A. L. Page, R. H. Miller \&
D. R. Keeney. Madison: American Society of Agronomy.

KNOWLES, R. (1977). The significance of asymbiotic dinitrogen fixation by bacteria. In $A$ Treatise on Dinitrogen Fixation. Section IV: Agronomy and Ecology, pp. 33-83. Edited by R. W. F. Hardy \& A. H. Gibson. New York: John Wiley.

KNOWLES, R. (1978). Free-living bacteria. In Limitations and Potentials for Biological Nitrogen Fixation in the Tropics, pp. 25-40. Edited by J. Dobereiner, R. H. Burris \& A. Hollaender. New York: Plenum Press.

MARMUR, J. (1961). A procedure for the isolation of deoxyribonucleic acid from microorganisms. Journal of Molecular Biology 3, 208-218.

MARMUR, J. \& DOTY, P. (1962). Determination of the base composition of deoxyribonucleic acid from its thermal denaturation temperature. Journal of Molecular Biology 5, 109-118.

MurRay, K., Duggleby, C. J., Sala-Trepat, J. M. \& Williams, P. A. (1972). The metabolism of benzoate and methylbenzoate via the meta-cleavage pathway of Pseudomonas arvilla mt-2. European Journal of Biochemistry 28, 301-310.

Palleroni, N. J. (1984). Genus I. Pseudomonas Migula 1984. In Bergey's Manual of Systematic Bacteriology, vol. 1, pp. 141-199. Edited by N. R. Krieg \& J. G. Holt. Baltimore: Williams \& Wilkins.

Postgate, J. R. (1981). Microbiology of the free-living nitrogen-fixing bacteria, excluding cyanobacteria. In Current Perspectives in Nitrogen Fixation, pp. $217-$ 228. Edited by A. H. Gibson \& W. E. Newton. Canberra: Australian Academy of Science.

Postgate, J. R. (1982). Biological nitrogen fixation: fundamentals. Philosophical Transactions of the Royal Society of London, Series B 296, 375-385.

Preston, C. M., Preston, J. M. \& Callway, E. G. (1981). Inexpensive ${ }^{15} \mathrm{~N}$ analysis of agricultural samples by optical emission spectroscopy employing a simple, one-step Dumas sample preparation procedure. Canadian Journal of Spectroscopy 26, 239244.

Rigby, P. W. J., Dieckmann, M., Rhodes, C. \& Berg, P. (1977). Labeling deoxyribonucleic acid to high specific activity in vitro by nick translation with DNA polymerase I. Journal of Molecular Biology 113, 237-251.

Robson, R. \& Postgate, J. (1980). Oxygen and hydrogen in biological nitrogen fixation. Annual Review of Microbiology 34, 183-207.

Robson, R., Kennedy, C. \& Postgate, J. R. (1983). Progress in comparative genetics of nitrogen fixation. Canadian Journal of Microbiology 29, 954-967.

RUVKUN, G. B. \& AUSUBEL, F. M. (1980). Interspecies homology of nitrogenase genes. Proceedings of the National Academy of Sciences of the United States of America 77, 191-195.

Singh, M., KLeEberger, A. \& Klinmuller, W. (1983). Location of nitrogen fixation (nif) genes on indigenous plasmids of Enterobacter agglomerans. Molecular and General Genetics 190, 373-378.

SOUTHERN, E. M. (1975). Detection of specific sequences among DNA fragments separated by gel electrophoresis. Journal of Molecular Biology 98, 503-517.

Stanier, R. Y., Palleroni, N. J. \& Doudoroff, M. 
(1966). The aerobic pseudomonads: a taxonomic study. Journal of General Microbiology 43, 159-271. ULITZUR, S. (1972). Rapid determination of DNA base composition by ultraviolet spectroscopy. Biochimica et biophysica acta 272, 1-11.
Wheatcroft, R. \& Williams, P. A. (1981). Rapid methods for the study of both stable and unstable plasmids in Pseudomonas. Journal of General Microbiology 124, 433-437. 